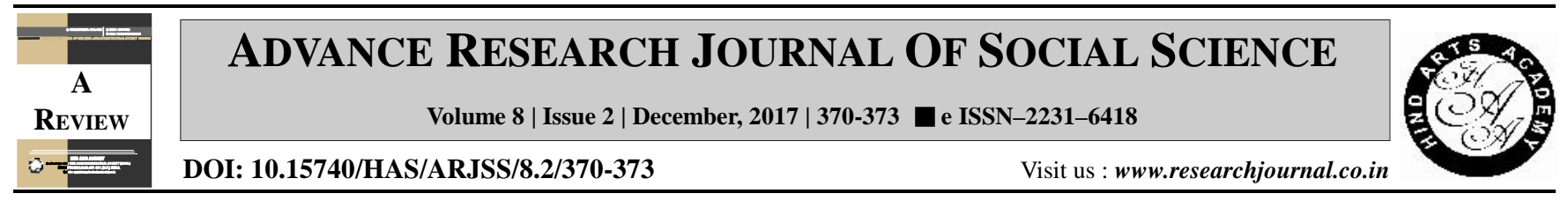

\title{
Graceful ageing: Challenges and prospects
}

Kalpana Anand

Department of Sociology, Vasant Kanya Mahavidyalaya, Kamachha, VARANASI (U.P.) INDIA

(Email: kalpanadiwedi86@gmail.com)

\section{ARTICLE INFO :}

Received

: 25.10 .2017

Accepted

: 24.11 .2017

\section{KEY WORDS :}

Ageing, Graceful ageing, Successful ageing

HOW TO CITE THIS ARTICLE : Anand, Kalpana (2017). Graceful ageing: Challenges and prospects. Adv. Res. J. Soc. Sci., 8 (2) : 370-373, DOI: 10.15740/ HAS/ARJSS/8.2/370-373.

\begin{abstract}
The dream of the people all over the world to live long is now becoming a reality due to the advancement in health and medical facility, social and economic development, scientific and technological revolution. But what about the quality of this extended life? Are people necessarily happier because they are living longer? What do most people want? The simple answer will be "they want love, useful work, safety and security, energy and health, power, fame and wealth to varying degrees, a long life with high quality and a society that provides support in achieving these goals". It means the people want to live long gracefully. It is basic issue that how older people think about successful aging and how he lives gracefully in society?
\end{abstract}

